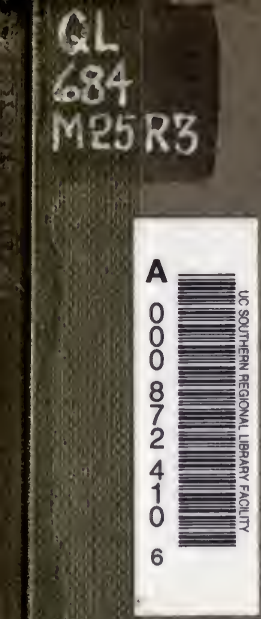


THE GIFT OF

FLORENCE V. V. DICKEY TO THE

UNIVERSITY OF CALIFORNIA AT LOS ANGELES
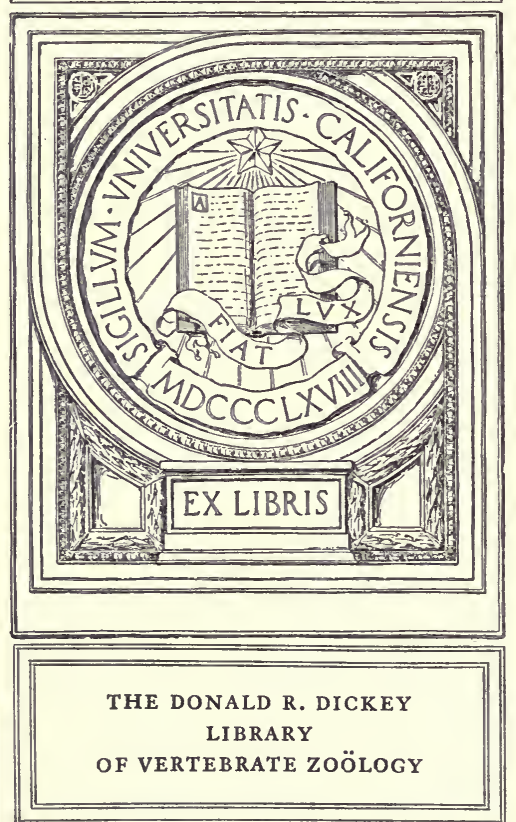


\title{
LIST OF BIRDS RESIDENT IN SUMMER NEAR THE CITY OF BALTIMORE.
}

\author{
Bx ARTHUR RESLER.
}

This list, which includes our resident birds, is based upon specimens collected and direct observations made in the vicinity of Baltimore, chiefly within a radius of five or six miles therefrom; but occasionally from a distance of twelve to fifteen miles southeast from the city, since I had frequent opportunities to visit that part of the country.

Excepting with regard to one species, sent to me for identification, I have confined myself to personal observations, and in no case have I relied upon the statements of other persons, nor upon the authority of the distribution of birds as generally recorded.

While it is not the purpose of this paper to write a natural history of our birds, nor to discuss questions of classification, it seems expedient to offer here and there such notes and remarks as may throw fresh light upon their peculiarities, habits and distribution. In further elucidation of the subject, the musical notation of a few songs of species are given, and such as will probably excite general interest. This procedure must, however, be considered as a first attempt, and rather as opening a branch of ornithology which the writer intends to pursue in the future as opportunities offer.

The nomenclature here given, in so far as the names, both scientific and common, are concerned, is that adopted by Mr. R. Ridgway in his "Manual of North American Birds," and the order here followed is that given in one of the older catalogues of the same author, published in the "Collections of the Smithsonian Institution." 
PART I.

\section{Order PASSERES.}

\section{Perching Birds.}

Turdus mustelinus (Gmel.). Wood Thrush.

This well-known bird, although not remarkable for brilliant plumage, surpasses most, if not all, of our songsters by the character of its song. This is in the highest degree musical, resembling the tones of a flute, or when heard from a distance recalling the flageolet tones produced on a violin. The principal strain may be given by the following musical notation :

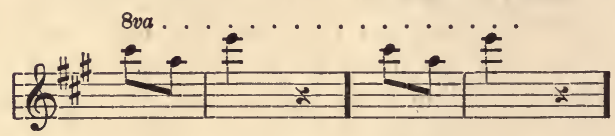

From early in May and throughout the summer until about the middle of August its song may be heard from the bushes and thickets, in the early morving or late evening, no matter what the weather may be, whether serene or overcast. This bird arrives toward the close of April and leaves about the end of September. During its stay it frequents shady woods, especially near the banks of a brook or small river. The nest, which is in part composed of mud, is usually attached to an alder bush, frequently about four or five feet from the ground. The writer found the young of this bird, not yet able to fly, in the early part of August, and these appeared to have heen representatives of a second brood. Although quite common, it appears to be not so well known as the majority of our other songsters, in consequence of being more solitary and shy, which tendency seems to increase toward the time of departure, when it stealthily makes its way through the thickets.

\section{Turdus unalascae Pallasii (Cab.). Hermit Thrush.}

While the capture last summer of a single specimen of this species seems to me purely accidental, I venture to place it here in order to give fulness to this list. The bird when taken was apparently in good health, and it was not one which had been 
detained by being hurt or crippled. The date of capture being in midsummer-July 9 th-excludes the idea of an early migration in this case.

The following observations, which were printed fur me in Forest and Stream, Vol. XXXV, No. 1, seem worthy of more permanent record: "On July 9th, while traversing the woods in Howard county, Md., about fifteen miles southwest of Baltimore, my attention was attracted by a thrush, which at once I saw was not the wood thrush (Turdus mustelinus). I shot the bird and was astonished to find it a hermit thrush (T. pallasii Cab.). The decided rufescent tail and tail coverts contrasted with the olive brown color of the head and back were sufficient to identify it. Knowing that there is no record of the occurrence of this bird in summer south of Massachusetts on the Atlantic coast, I give some account of its characteristics. Comparing it with the descriptions in Ridgway's 'Manual,' Cones and Baird, and with a mounted specimen in my collection, shot in fall, I could find no difference except in the bill, which, though not as bulky as that of the wood thrush, is longer and broader than in the mounted specimen. The measurements from the nostrils to the tip of the bill were as follows: Mounted specimen of T. pallasii, .36 in.; the above specimen of the same species, .40 in. ; T. mustelinus, .48 in. That this bird was not a young specimen of $T$. mustelinus is shown by the fact that a young bird of that species which I caught with my hands, and which had the tail only half developed, showed the cinnamon color of the head, the spotted sides beneath and the olive brown color of the tail, while in my specimen of $T$. pallasii the colors of the various parts differ in no respect from the mounted specimen in my collection. On dissection this bird proved to be a female. The œsophagus contained the whole of a grasshopper, apparently the larva of œdipoda. Before concluding, I desire to speak of the time of arrival and departure of this species in the immediate vicinity of Baltimore. About the first or second week in October it makes its appearance, and is very common through that month, its number diminishing gradually as winter approaches. The last specimen I obtained in fall was November $23 \mathrm{~d}$. A few remain here throughout the winter, as I have 
shown in a paper printed in Forest and Stream, Vol. XXVIII, No. 6. The earliest date in spring at which I procured a specimen was March 5th, but toward the middle or close of the same month it becomes more plentiful. About the close of the following month it disappears entirely."

\section{Merula migratoria (Linn.). American Robin.}

The Robin is one of our most abundant and best known birds, familiar alike to the farmer and to the gunner. The habit of this bird is but partly migratory, but the greater number seem to winter farther south than this climate, becoming plentiful the middle, and sometimes not until the close of February. The following month they are found all over the country, congregating in small flocks, which disband as spring advances. In fall, especially in October, flocks are again formed, and the number of birds is greater even than in the spring. As winter approaches there is a steady decrease in these numbers, with a glimpse now and then during the winter, until the spring finds them with us again.

During the fall migration the robin shows a decided partiality for the fruit of the sour-gum tree (Nyssa Sylvatica). This preference it has in common with the "flicker." The nest greatly resembles that of the wood thrush, in that both contain mud in their composition, but owing to the less shy disposition of the robin, its home is often made in close proximity to men. Nests have been observed at places where hundreds of people would pass, in fact at popular resorts, and the bird showed no signs of fear, the nest being situated, however, well up the tree, where it could not be easily disturbed. .

\section{Galeoscoptes carolinensis (Linn.). Catbird.}

With regard to the name of this bird the Latin saying, "Nomen est omen," well applies. Owing to the law of priority, the species name "filivox," which aptly describes the bird, must be set aside for that of carolinensis, which virtually means nothing. Being equally common in New York, Maryland and Virginia, the name would have been as descriptive, as it now stands, had 
it been virginicus, etc. This dark-colored songster arrives in this vicinity about the latter part of April, leaving some time in October, having been observed as late as the $22 \mathrm{~d}$ of that month. The arrival is made known by the characteristic cat-like notes. Besides these sounds the bird has a regular song, no order in the strains, but reminding one of the chatting and gabbling of talkative people, amusing however to the listener, and seemingly also to the singer. The nest, situated in bushes and briers of every description, along roadsides or near the farm house, is made of dry leaves, small rootlets, and stalks of different weeds. Even rags and pieces of paper have been found in the composition. In the construction of the inner lining smaller rootlets are used than on the exterior of the nest. The eggs, usually five, sometimes only four, are of a very dark bluish-green color, and show no indications of spots. Nests containing eggs are found all through June.

\section{Harporhynchus rufus (Linn.). Brown Thrasher.}

This songster is better known under the common names of "Red Thrush" and "Sandy Mocking-bird," but the latter is the name by which it is best known by our farmers and people generally. The bird is as common as the catbird and frequents the same places, but its habits are not the same. The sandy mocking-bird delights in the early morning to rest upon some tall tree or telegraph wire by the roadside and peal forth its beautiful and vigorous song. Another habit is to run in thickets or even small open places, scratching the ground, and among the dry leaves searching for insects. The nest is not a very fine structure, and is placed among bushes and brambles. It contains four or five brown-speckled eggs, which are somewhat larger than those of the catbird. Judging by the different months in which eggs have been found, the writer concludes that two broods are hatched during the season. This bird appears early in April, about the first week, and departs for the South about the first week in October.

Sialia sialis (Linn.). Bluebird.

This well-known bird is but partly migratory in its habits, 
seldom entirely leaving us during the winter. On ornithological excursions during the months of December and January one rarely fails to see this bird, but February brings to us the majority. This, however, is dependent on the exigencies of the season. The blue garb makes this bird conspicuous everywhere, especially since it does not seek to conceal itself in shady woods or bushes and thickets. The song is a plain warble. Beside these regular notes, there is a call-note which is very characteristic, and which cannot easily be confounded with that of other birds.

The nest is placed in holes, usually in an old cherry or apple tree. The eggs are of pale blue, and in shape are, on the average, a little more globose than those of the catbird. It is hardly necessary to state that our bird is an exceedingly common and abundant species, except, as above mentioned, during winter.

\section{Parus bicolor (Linn.). Tufted Titmouse.}

The "Tufted Titmouse," also known as the "Crested Titmouse," is one of our resident birds, and may be found almost anywhere in the depths of the woods, or among the trees and shrubs that border our waters. In winter it associates with various smaller birds, as for instance, chickadee, creeper, et al., and is quite common near the suburbs, and has been seen and heard even in the midst of the city. During the summer months, however, this species seems to retire to a part of the country less densely populated. Though quite common, it is not so abundant as the next species, that is as regards the immediate vicinity of the city. Being of a somewhat more shy and suspicious disposition than its relative, the chickadee, this might be easily explained.

The most distinctive characteristic of the tufted titmouse is the whistle, consisting of two tones, forming a fourth, as here indicated:

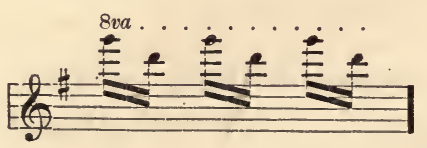


Besides this it possesses a few other very squeaky notes, entirely at variance with the musical whistle, and both may be heard throughout the whole year.

\section{Parus carolinensis (Aud.). Carolina Chickadee.}

This restless little bird is likewise a resident, sharing with the preceding species the same habits and frequenting the same localities. The Chickadee, like the titmouse, prefers the vicinity of the city mainly, if not wholly, during the colder season. In winter, whenever and wherever we may go, we are sure to find these jolly birds. They form little parties amongst themselves, or in company with the creeper and "golden-crowned kinglet," and soon make their presence known by their incessant squeaky notes. Besides this unmusical squeaking, the chickadee possesses a very simple, although neat little song, which may be given by the following syllables, Twe-da-we, twe-da-wit, given with a kind of nasal twang. This strain is heard not only during the summer, but also during the winter. The nest, an exceedingly cozy-looking structure, is made partly of moss. One nest, found early in May, was hid in the stump of a small tree about five feet from the ground, and contained six eggs. The eggs were white with a faint rosy tinge and speckled with reddish brown, these speckles predominating near the thicker end. The appearance of the eggs did not indicate that incubation had begun.

Sitta carolinensis (Lath.). White-breasted Nuthatch.

Of the two species of Nuthatches which the writer has observed near Baltimore, this is the more common, and the one which remains with us during the warm season. It is in the fullest sense a resident bird; and it is in my opinion the best climber of our woods, not even excepting the species of woodpecker. When we consider the absence of support from the sides of the tail, the feathers there being soft, and observe its practice of climbing downward, we are constrained to admit that it possesses qualities not attained by the most advanced of the woodpeckers. The absence of a scansorial tail, of course, forces the bird to rely for support solely on his feet, and this causes a 
kind of climbing different from that of the woodpecker. This bird is easily recognized by its notes, whigh sound like "quank," and can be heard for some distance. It may be found in woods of all kinds, and also among the trees that border the rivers, which it does not leave unless forced to do so. It may not be amiss to mention the older and better known English name, White-bellied Nuthatch, but the name above given is to be preferred, as the difference in the two species is more marked on the breast than on the belly.

\section{Thryothorus ludovicianus (Lath.). Carolina Wren.}

The powerful and very musical notes of this bird command our attention. Especially is this so during winter, when our migratory songsters have left us and our remaining ones are voiceless. Now here, now there, we hear the notes, and often considerable time is required to locate the singer. We become familiar with the song long before we know the bird that makes it. Wilson represents this song by the words, "Sweet William," but some imagination is required to make the sounds coincide. It may be more accurately given by the syllables, "Dee-deed-la, dee-deed-la," generally speaking, but sometimes the sounds come nearer "Dee-deea." The musical notation would be about-

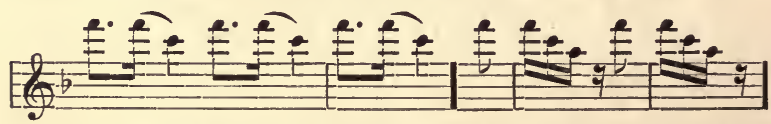

I have often wondered at the seeming indifference of this bird to the seasonal changes of our climate. It has been heard pealing forth (sit venia verbo) its strains in summer when the thermometer registered ninety degrees, and again on one occasion in winter, when the temperature was below twenty degrees. The bird is usually found in bushes, shrubs and small trees near some brook or rivulet. One specimen was obtained from the top of a rather tall tree, but that abode was so unusual that a memorandum was made of the fact. This wren is by no means uncommon, neither is it abundant. It is a resident bird, and no difference has been observed in its distribution during either winter or summer. 
It has been noticed that there seems to be a spirit of rivalry among these birds when singing, one trying to outsing the other. They also answer one another, and it is worthy of remark that the answers are not given in the same pitch.

\section{Troglodytes aidon (Viell.). House Wren.}

About the latter part of April, this "house friend" makes its appearance. As the common name indicates, this wren especially prefers the neighborhood of men, and breeds regardless of their proximity. If a box be provided in a tree near the house, the nest is built there, or in some convenient hole in the house. On account of its familiarity this species is liked wherever it makes its abode, whether it be near the farm house or in the city. In the city of Baltimore it is not as common as formerly, probably, if not certainly, on account of the presence of the "English Sparrow." The song of this bird is a kind of warble; soon recognized, but difficult to indicate, either by syllables or words. In the beginning of October, about the time of the arrival of the "winter wren," the house wren takes its leave. This species is seen to be more abundant than the preceding.

\section{Cistothorus palustris (Wils.). Long-billed Marsh Wren.}

In its nidification and the localities which it inhabits, this wren differs greatly from its relatives. In the marshes and swamps of our rivers, for instance Back or Patapsco, where covered with "water oats" (Zizania aquatica), and reeds, mostly "cat tail," with here and there a patch of pickerel weed (Pontederia cordata) we find the wren in adundance during the entire summer. It arrives here late in April and remains until near the end of September, and sometimes a straggler is found as late as October. This bird affects exclusively swamps and marshes, and has not been observed to venture away from the water, since its chief delight is to scramble up and down the reed stems growing there. Now and then, one will rise a few yards straight into the air, during this time lustily singing, if indeed we can so call their screeching and crackling notes. 
Wilson compares these uotes to "the crackling sound, similar to that produced by air bubbles forcing their way through mud when trod upon," but this is rather too hard to state about our little friend. The nest is a semi-globose structure, hollow, with a hole on one side. Being composed mainly of the leaves of the reeds, interwoven with one another, with some hanging down or sticking out, it does not present a very neat appearance. This nest is always attached to the stems of the reeds, usually typha, and so constructed that sometimes as many as five or six of the stems pass through its walls, thereby making it very secure. The eggs are small, about five or six in a set and are of a dark color, similar to that of chocolate. The writer has found nests with eggs early in June, and again in July, making it extremely probable that there is more than one brood in a season.

Mniotilta varia (Linn.). Black and White Warbler.

Of the smaller birds that inhabit our woodlands, the "Black and White Creeper," as it is usually called, is certainly one of the most characteristic. This bird climbs the trees in all directions, with a dexterity and agility entirely foreign to our other warblers, and only to be found again in the true "creeper," a common winter bird whose place it seems to take during summer. The writer has never heard the bird utter sounds that might be called a song, the only notes given forth being some screeching ones, usually uttered as it flies swiftly from one tree to another. It arrives in this region about the third week in April, and leaves in October, having been observed as late as the ninth of that month. This species is rather abundant in suitable localities, and not possessing a shy disposition, its habits may readily be observed.

Helmintherus vermivorus (Gmel.). Worm-Eating Warbler.

Although a regular summer visitor in this latitude, we have to consider this Warbler as a rather uncommon bird, and one which has been nowhere found abundant. It seems to prefer woods and groves composed of small trees and bushes, with thick un- 
dergrowth, where it is observed to fly from tree to tree as if in search of insects. Its motion reminded me sometimes of the darting of the flycatchers. The bird was formerly to be found among the groves and copses bordering the Back and Patapsco rivers, and did not appear at any time fond of running on the ground. It remains continuously from about the 10th of May until some time in the month of September.

\section{Dendroica aestiva (Gmel.). Yellow Warbler.}

Of the genus "Dendroica" proper, this is our most common species, and the one which, owing to its habits, may be most readily observed. The "Yellow Warbler" frequents small trees and shrubs along the road, or willows and similar trees along the water, and even visits our gardens and yards, especially on its arrival, which is about the 24th of April. As early as the second or third week in September, it takes its departure. The notes, although not very remarkable, make a pleasant warble, sounding something like the syllables dui-dia-dee.

\section{Dendroica discolor (Viell.). Prairie Warbler.}

One not acquainted with the notes of this little warbler might readily conclude that it is a rather rare summer visitor. Although not quite so common as the "yellow warbler," in suitable localities it is abundant all through the summer. The favorite habit of the bird is to hide in the foliage of some evergreen, for example the cedar, but it does not adhere exclusively to such trees, and betrays itself by the curious notes of its song. The notes sound like the syllable "Ts," which gradually grows higher and louder, and abruptly terminates with the syllable "Ee-a," pronounced with emphasis. The time of the arrival in - this locality is about the same as that of the "yellow warbler," and the departure takes place in September.

\section{Dendroica vigorsii (Aud.). Pine Warbler.}

Early in April, the Pine Warbler makes its appearance, and becomes more abundant throughout this month in all suital,le localities. Later on, the numbers greatly decrease, so that as 
summer advances it becomes less numerous than most of our other warblers. In the fall, and especially towards the time of its departure, near the end of October, it once more becomes numerous. Both in the spring and fall, the writer found this species in barren grounds and fields, overgrown with small pines, such localities, without doubt, being preferred by it. Nevertheless, we obtained specimens in shrubbery and undergrowth, as well as in some woods, destitute of coniferous trees. During the period of migration, it gathers together in flocks, composed of a dozen or more individuals, which alight on the small pines and at times are also seen on the ground. Except a chirp, common to most of the smaller birds, the writer has never heard it utter a sound which might be called a song.

\section{Seiurus aurocapillus (Linn.). Oven Bird.}

One of the most common birds to be found in the woods during the summer is this species, better known under the name of "Golden-crowned Thrush." Soon after its arrival, which is about the 20th of April, the woods almost ring with its loud voice. The song consists of but one syllable or tone, frequently and rapidly repeated. This song, if once heard, can with ease be always distinguished from that of other birds. In sunshine or rain, even during thunder and lightning, the loud notes of this species have been heard. It delights to run on the ground among the leaves, after the manner of the "towhee," and the "red thrasher." This warbler is distinctively a woodland bird, and is seldom, if ever, observed outside of such places.

The nest is placed on the ground and is usually covered, and has an opening on one side. This mode of construction of the nest has caused the bird to be called "oven bird." About the middle of October it leaves us, the 18th being the latest that it has been observed, but long before that time it has become silent and retired.

Seiurus motacilla (Viell.). Louisiana Water Thrush.

According to our observations, this is a rather rare species around Baltimore. The few that have been noticed have been 
seen in damp woods, along the side of a brooklet, during the month of May and again in July, and seem of a rather shy and quiet disposition. Its song is as yet unknown to the writer.

\section{Geothlypis trichas (Linn.). Maryland Yellow-throat.}

This dainty little bird arrives in this latitude about the 20th of April. In October it moves south to more congenial quarters, the 10th of that month being the latest that any have been noticed. This species is one of our most abundant summer birds, frequenting bushes, brambles and all kinds of undergrowth in the neighborhood of water, and, like some of the wrens, it has been observed even among the reeds in marshes. The song cannot be better imitated than by the syllables Wilson has already given, viz., "Whititee," the accent being on the first syllable. But the note habitually and more frequently heard, is a kind of chuck, a call note, common to many of our smaller birds. An acute observer can usually distinguish the different birds, even though the call notes resemble one another.

\section{Icteria virens (Linn.). Yellow-breasted Chat.}

This is certainly one of our most interesting and characteristic birds. The song or notes, be it what it may, is such a mixture of all possible sounds, that it really astonishes one. Such an incessant chatting and gabbling is kept up, that the bird is readily distinguished, for not one of our other birds exhibits such peculiarities. This bird is common, but is usually more frequently heard than seen. Often, when after considerable effort we seem to have located the place from whence the sounds come, we look and watch in vain for a glimpse of the bird.

The nest is usually placed among the thickest briers and brambles, and is composed chiefly of dry leaves for the exterior, the inner lining being of thin strips of grape-vine bark. The eggs, four or five in number, are white, with brownish spots. This bird arrives here about May, and leaves late in August, the writer never having observed a specimen after that month. 


\section{Sylvania canadensis (Linn.).}

This is one of our rarer summer birds, which during the spring and fall migration is not at all uncommon in its favorite localities. The disposition of the bird is quiet and retired, dwelling in trees and busying itself in the catching of various kinds of insects. It is most common during the first and second weeks in May; after that time the number becomes gradually smaller, and, as a rule, not many remain with us during the summer. In September again it becomes more numerous, but soon leaves us for the winter. The writer has had no opportunity of hearing the song, and consequently can make no remarks upon it.

Setophaga ruticilla (Linn.). American Redstart.

From the latter part of April until early in October this species is a constant and common inhabitant of our woods. The habits of this bird are the same as those of a flycatcher, while on the wing constantly pursuing little insects, and diving, so to speak, after them in all directions. The notes are meagre, and it is almost impossible to imitate or represent them by words or syllables. Sometimes notes are uttered which sound like the noise made by the smacking of the tongue.

\section{Vireo olivaceus (Linn.). Red-eyed Vireo.}

Of the three species of Vireos that the writer has observed near Baltimore during summer, this one is by far the most common. This agreeable little bird may be met with almost anywhere except in coniferous woods, which it does not frequent. Its appearance the latter part of April is soon recognized by the pleasant and continuous warble. Owing to its plumage, which the name bespeaks, the bird is well protected by the green foliage of the trees which it inhabits, and for this reason is easily overlooked as it becomes silent on the approach of September. It does not leave us until the close of that month, and has been observed as late as October 5th. The nest is pensile, is placed in a small oak, and is attached to two twigs, which are sometimes, but not always, forked. In appearance it is basket-like, 
and composed of various kinds of material, such as leaves, pieces of wasps' nests, strips of bark, etc. The inner lining is composed of fine strips of the bark of the grape-vine and the stems of grasses. It has been stated that hair is used in this lining, but the writer has never met with it in his observations. The eggs are pure white, irregularly marked near the thicker end with small dark brown specks. In a set of four eggs, three were observed to have a few dots near the smaller end, which were missing from the fourth. This set was taken in the second week of June.

\section{- Vireo noveboracensis (Gmel.). White-eyed Vireo.}

This species makes its appearance about the same time as the red-eyed vireo, to which it is closely related. The writer has observed it in the fall, not quite as late as the former. Its ways are a little more vivacious and sprightly, but it frequents iearly the same localities, and its nidification is not essentially different, while its notes are quite distinct from those of that species. It seems to be quite common in this region, but less abundant than the red-eyed vireo.

\section{Vireo flavifrons (Viell.). Yellow-throated Vireo.}

During the period of migration this species is not so abuudant as the two preceding ones, and in summer the difference in numbers is much greater. It frequents the medium-sized and large trees of woods in company with birds of its own kind, but sometimes with other vireos. The notes are rather weak, not nearly so loud and vivacious as those of the two preceding vireos, and show a marked difference in that respect. It arrives in this vicinity during the latter part of April and leaves toward the close of September.

Ampelis cedrorum (Viell.). Cedar Waxwing.

This well-known species, commonly called by the farmer Cedar Lark, may be observed from early in March throughout the summer until the early part of December, but varies greatly 
in numbers according to the season. During March and April it is not abundant, but may be met with occasionally. Throughout May, and even in June, it collects in flocks in localities suited to its wants, and always frequents woods in preference to shrubs and bushes, and in the fall feeds on different kinds of berries. The bird breeds late, as may be inferred from its keeping in flocks so late in the season. It has no song, nor does it give forth any peculiar notes. The nest is rather large for the size of the bird, is not at all neat looking, is almost entirely constructed of dry stalks of grasses, sometimes of poa, and is usually placed on an apple or other tree in the orchard. Rootlets and stalks of small plants which are common in yards and orchards, such as plantago, are also used in the construction of the nest. The eggs are three or four in number, of a bluishgray ground color, thickly specked with small and smaller brown dots near and around the larger end, near the middle marked with some irregular, dark purplish-brown blotches, which are sometimes confluent, while around the smaller end there are only a few small dots. Besides these, the eggs have some irregular smaller spots of pale purple between the dark spots. One nest containing three eggs was obtained in the second week of July. Whether these belonged to a second brood or to a retarded first brood, we are not able to state.

\section{Chelidon erythrogaster (Bodd). Barn Swallow.}

This swallow, like the rest of its tribe, is one of the earliest birds to arrive from the South, reaching this vicinity about the first of April, at which time it is liable to be overtaken by cold and snow. Coming as it does, in large numbers, it is well known and liked by every one. Its habits are so familiar that it is unnecessary to make extended remarks upon that subject. As is well known, it breeds in barns and similar buildings. The cup-shaped nest is composed mainly of mud, and is fastened by one side to boards and planks of the different buildings. Toward the close of August it begins to collect in large numbers, which are continually increasing, and about the twentieth of September it departs for the South. 
Tachycineta bicolor (Viell.). White-bellied Swallow.

This beautiful swallow arrives early in April. It is very common and abundant during the spring, but is less so in the summer; the barn-swallow at that time being the more common of the two. It leaves this region early in September, and appears to be more attached to the water than the foregoing species.

\section{Progne subis (Linu.). Purple Martin.}

This is the largest, and, as far as the adult male is concerned, the darkest colored of our swallows. It is common throughout summer in open places, breeding near houses in boxes or other contrivances made for its use by the people. We have observed it as late as to near the middle of September. It delights to perch in company with the barn and cliff swallows on the telegraph wires of the roads, now and then darting off and making aerial evolutions, while the others clean their plumage or sing in plain and simple notes composed of guttural sounds.

\section{Petrochelidon lunifrons (Say.). Cliff Swallow.}

This bird has never been found by the writer to be numerous in this vicinity, either in spring or summer. During the latter part of summer we have observed it in company with the martin and barn swallow. The habits, time of arrival and departure are about those of the other species mentioned.

\section{Clivicola riparia (Linn.). Bank Swallow.}

This bird arrives in April, it is extremely common and associates in great numbers with its own kind. It frequents the banks, cliffs, etc., of our rivers and streams, and of the Chesapeake Bay. It breeds in holes made in these places. On one occasion, in July, at Bay Ridge, below Annapolis, at least two hundred of these holes, some close and others wider apart, were dug in all directions into the almost perpendicular cliffs, out of which holes the swallows would fly back and forth with the activity of a nest of bees. The eggs, which are laid in these holes, are white. About the middle or close of September it departs to a milder climate. 
Stelgidopteryx serripennis (Aud.). Rough-winged Swallow.

This species is without doubt our rarest swallow. It is a regular summer visitor, which frequents the same loealities as the bank swallow. On several occasions we observed it to enter holes in banks, not far from one occupied by a kingfisher, but nothing certain could be found out as to whether it had been breeding or not. The time was early in June, when it should be ready to breed, and a pair was noticed in the same locality for a few consecutive weeks. Unlike the preceding species, this is not at all social, and it is never seen in large communities. It may be observed from April 19th until the middle of September. There is nothing peculiar in its notes.

Piranga erythromelas (Viell.). Scarlet Tanager.

This elegant bird arrives here usually about the beginning of May. It is generally distributed over the country in woodlands, and frequents preferably the tops of trees with thick foliage. The usual notes are some kind of a chirp, besides which it has a few whistling notes, not very loud, but quite pleasant to the listener. Nevertheless, as the bird is of a quiet disposition, it does not make much use of its capabilities as a singer.

Although a regular inhabitant of our woods, it does not seem to be abundant anywhere. It is of a solitary disposition, and notable for its neglect to seek the company of others, even of its own kind. Towards the end of August it prepares to leave this region, and so regular is its migrating that we have thus far failed to find even a single individual as late as the 1st of September.

Piranga rubra (Linn.). Summer Tanager.

This Tanager, better known under the name of "Summer Redbird," is much rarer than the "scarlet tanager," as well during the period of migration as throughout the summer. It arrives here about the second week in May, or a little later than the "scarlet tanager." Early in September it leaves us, and 
the 5th of that month is the latest date at which the writer has seen specimens. Those have always occurred to us in woods, where it frequents the tops of trees much after the manner of the other tanager. Its song possesses some peculiarly strange notes, which attracted my attention before the bird had ever been within reach of my sight.

\section{Spinus tristis (Linn.). American Goldfinch.}

This one of our resident birds is common alike in summer and winter, nor did I ever notice that during the time of migration their numbers were greatly increased, as is the case with many of our other birds. The species almost always collects in flocks, especially during the colder season, when it often accompanies the snowbird, and other sparrows in running over the ground after food, or in hanging to stalks of weeds while searching for seeds. In winter it shows a decided fondness for the fruits of the common alder. When on the tree, the individuals sit so close together that at one time, much to my regret and surprise, at a single discharge of my gun, five birds fell to the ground, notwithstanding the fact that my gun was charged with only a very small load of shot. It flies very singularly, in curved, or more correctly, undulating lines, up and down, every now and then uttering its well-known notes, which sound like "Doo-i," the syllable " $\mathrm{i}$ " being accented.

The nest is cup-shaped, very neat looking, and placed not far from the ground on a small tree. The eggs are usually five in number, and of a whitish color.

The plumage of the male, as is well known, undergoes considerable change early in the fall, notably in September. Several names have also been applied to the bird, such as Thistlebird and Yellowbird, but "Wild Canary" is the one under which it is best known by our farmers and other people.

\section{Poocaetes gramineus (Gmel.). Vesper Sparrow.}

The "Grass Sparrow," as this species is commonly called, has been observed by the writer from early in March (3d) through 
the summer until late in the fall, but it is not at all as abundant during summer as it is in the spring, especially in April and the greater part of May, the majority evidently go northward; Maryland and Virginia being about the southernmost breedingplaces. This species probably also winters here, since we have obtained a specimen as late as the 6th of December. This, however, seems to have been an exceptional instance, as the species has never been observed by us at a later date, although it has been eagerly looked for, and this bird is easily enough observable at any moderate distance. Grass and clover fields are its favorite haunts, as also grassy sloping banks along railroads. It prefers to keep to the ground and is hardly ever to be seen perched on trees, but when exceptionally met with there, is never perched at any great distance above the ground.

\section{Ammodromus savanarum passerinus (Wils.). Grasshopper Sparrow.}

Of our Sparrows proper, this is without doubt the least abundant species. In fact, as far as the immediate vicinity of this city is concerned, it can by no means be called an abundant bird. It has been observed by us from May throughout summer until October, frequenting the fields and pastures, and running on the ground like the grass-sparrow. Now and then it mounts a fence or some small bush, but it prefers to stay on the ground. With regard to the name, it is better known as the "Yellow-winged Sparrow," which has been used to designate it by all the earlicr ornithologists.

\section{Ammodromus maritimus (Wils.). Seaside Sparrow.}

This is the only species in the present list that I have not observed alive. One specimen was collected some five or six years ago on Miller's Island, by the late Mr. Wolle, Sr., at whose house I had the opportunity to examine the bird before it was mounted. As it was unknown to Mr. Wolle, who had handled so many of our birds, I was led to the conclusion that it is a rare visitor in this section of the country. 


\section{Melospiza fasciata (Gmel.). Song Sparrow.}

This species may be found the whole year through. As far as my observations extend, its numbers do not decrease in winter - even if the weather should be severe. It frequents the borders of various bodies of water, both great and small. Especially during winter it may be found in swampy spots overgrown with reeds, shrubs and small willows. During that season it may also be found associated with the snowbird and other small birds, congregating in flocks, running on the ground like little mice, and busily engaged in searching for food. As a singer it is not surpassed by any of the other sparrows. During the whole year, not excepting the cold season, its pleasant notes may be heard. The strain is usually as follows : three or four distinct moderately high notes, often embellished by grace notes, followed by a lower note, which is given forth with a peculiar squeaky twang not in accord with the rest of the song, and succeeded by a very high trill, which is finished with a still higher note.
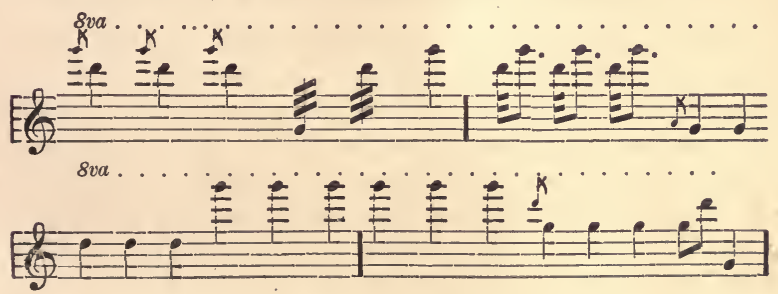

'1 he nest is usually placed on the ground, and it is composed of grass, the inside being lined with horse-hair, in which are placed four or five eggs, thickly spotted and blotched with brown.

Spizella pusilla (Wils..) Field Sparrow.

This little sparrow remains with us in small numb3rs throughout the winter, but the majority of specimens leave about the month of November upon the approach of severe weather, while in the month of March its numbers may be seen to increase. During summer it is distributed everywhere excepting in the woods, and it is not confined, as its name implies, to the fields. 
It may be found along the roadsides as well as in the hedgerows and bushes, and often perched on a tree or telegraph wire, which latter seems to be one of its favorite resting places. There it utters its few simple notes in a rather faint and high-pitched tone, differing entirely from those of the song sparrow. The nest is chiefly conposed of fine grass stems, lined with horsehair. The eggs are white, usually tinged with green and spotted with rusty brown.

In January last the writer obtained one specimen which was partly an albino. The top of its head, some of the larger and smaller feathers of the wing coverts and a few of those on the back and in the tail were snow-white. No definite pattern of color was here observable, but the markings were irregularly distributed over the upper part of the body.

\section{Spizella socialis (Wils.). Chipping Sparrow.}

This lovely little species is quite as common as the field sparrow. It arrives here in March and remains throughout October. According to my own observations it does not winter here, since the most eager search has failed to yield me a single specimen during that season. This bird is more familiar and attached to man than any of our other species. While there are others which live in as close proximity to houses, and still others which lose their shyness when driven by hunger, our bird may be seen at excursion resorts and picnic grounds hopping around our feet searchiug for crumbs without showing the least fear, and this it does at a time when there is plenty of food everywhere, and no occasion for the bird to abandon its natural shyness and timidity. Its song is a pleasant warble, not so faint as that of the field sparrow. The nest is composed chiefly of slender grass stems, occasionally mixed with threads, and is lined with horse-hair. We have found it on apple trees in the orchard, likewise beside the road on a blackberry bush not more than three or four feet from the ground, and once attached to a porch. We have. observed the female incubating in the month of August. The eggs are usually four or five in number, of a light greenish blue 
color, blotched and speckled near the larger end with various shades of brown or dark purple, and often have small dark spots distributed here and there over most of the surface.

\section{Pipilo erythrophthalmus (Linn.). Towhee.}

About the middle of April the Towhee, better known under the name of Ground Finch, or Ground Robin, makes its appearance. The earliest date of arrival observed by me has been about the tenth of that month. From the date of its arrival, and continuing all through the summer until the time of departure, it is one of our most common birds. It occurs almost everywhere, and may be seen near hedges, along the roadside in shrubs and bushes, and in all kinds of thickets. Owing to its size, color and habits, it is well known to our farmers. Often it may be seen on the ground, like the Red Thrush, scratching up the leaves in search of food, and thereby causing a quick rustling noise, especially when several individuals have collected together. This species seems to avoid the depths of the woods. 'The nest is placed on the grouud, and appears rather large and slovenly looking. It is built chiefly of fresh grass-stalks, the outside, excepting the lowest part, being composed of various dry leaves, with the thin, flexible stems, sometimes a foot in length, woven into the grass-stems, which give the outside a coarse appearance, and especially as the nest is surrounded by dry leaves. Oak leaves seem to be the kind which it prefers for that purpose. The eggs are rather large, of a whitish ground color, blotched, speckled, and spotted all over with reddish brown, but more closely so near the larger end. Between the darker blotches there are also some faint lilac spots, which may be seen by close examination. The usual number of eggs seems to be five. A nest was found by the writer on the fifteenth of August, in which were three newly hatched young ones, which could hardly have been more than one or two days old. These, we are quite confident, must have belonged to a third brood. The smaller number of eggs represented by these young birds may be accounted for by the lateness in the season. This nest was situated in a small bush, not, as usual, on the ground. 
The usual notes are "Tow-hee," uttered sharp and distinct, and with the second syllable accented. Besides this note, the bird gives forth another quite pleasant little strain, which may be imitated by the syllables, "Dya-dee-didrr."

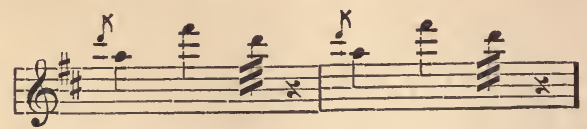

During the latter part of October the Towhee leaves for a more pleasant temperature, so that by the first of November the writer has always failed to discover it. It seems doubtful that this species ever winters in this latitude, as has been asserted by several observers.

\section{Cardinalis cardinalis (Linn.). Cardinal.}

This dignified and brilliant colored bird stays in this region throughout the year, and it is just as common during the winter as in the summer. While being one of our most conspicuous in summer, it is even more so in winter, when the leaves no longer cover the trees. It is distributed almost everywhere, excepting in the fields and higher woods, but it also ventures to appear around the farm-house, and is quite familiar to the country people, who call it by the name of "Red Bird" in preference to that of Cardinal. The bird is usually found in pairs, and even iu winter the writer has rarely seen one flying into a bush or thicket that has not been followed by a second individual. At such times it utters a peculiar call which sounds like "zeett," and this call may be heard at all seasons of the year. Besides the above cry, it gives forth a fine song, which may be heard from early in March until the close of summer, and during all this time it is a most indefatigable songster, repeating its strains at frequent intervals.

The nest is placed in small trees, besides bushes and brambles. It is made of fine rootlets, bits of weeds and strips of the bark of grape-vine. Its eggs are whitish, and marked with various shades of brownish. 
Passerina cyanea (Linn.). Indigo Bunting.

The "Indigo Bird," as this is commonly called, arrives here early in May; it is consequently one of the later birds in its return. All through the summer it is a most abundant songster, and in the autumn we have observed it as late as the 5th of October. While resident here it chiefly frequents the borders of woods, but it may also be seen on trees and shrubs next the roadside, or near the buildings on the farm; at other times it likewise perches on the wire of the telegraph lines. From its color and habit of remaining unconcealed it becomes well known to our farmers, who call it by the name of "Little Blue Bird." This bird has a very pleasant little song, which suggests the syllables "Di-a," repeated four or five times, and finished with a high-pitched but not sharp note. This song is renewed with great persistence, while the bird rests fully exposed to view on the branch of some tall tree or the telegraph wire.

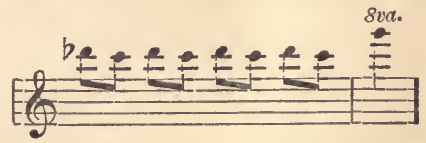

The nest is placed on a bush, not far from the ground. One nest was found by the writer on a small sassafras tree, about four feet from the ground, which was suspended by three twigs. It , is built chiefly of grass, sometimes with pieces of rags on the inside. The eggs are white, with a bluish tinge. A nest was found by me as late as second week in August, in which were three young birds, probably not more than two or three days old. Returning to the nest shortly thereafter the young ones were absent, although they could hardly have been old enough to fly.

\section{Spiza americana (Gmel.): Dickcissel.}

The neighborhood of Baltimore does not seem to be one of the favorite localities for the residence of this bird. Althongh there are times when it appears to be rather common here, at other times we have been unable to detect a single specimen, even in places where it was previously to be found, and where 
no marked changes had taken place in the character of the country. This plain, but neat-looking bird selects grassy places and the borders of fields near roads, and there it may often be seen perched upon a fence, pouring forth its song of simple notes. It arrives here about the second week in May, and generally leaves during the latter part of September. We have observed a single specimen as late as the second day of October. It may also be mentioned that this bird is better known here by the name of "Black-throated Bunting."

\section{Molothrus ater (Bodd.). Cowbird.}

Early in April, or about that time, the "Cowbird" makes its appearance, but it does not seem to be abundant near Baltimore; and especially throughout summer it is only occasionally to be seen. During the fall, however, particularly in October and part of November, it appears quite common; frequenting the same localities and spots as the swamp blackbird. It may be seen flying to and fro over the marshes in the same manner as that species, in small flocks, and often associating with it and the "Rusty-wing Blackbird."

On one occasion, with one load of shot, we brought down a cowbird, blackbird and a rusty blackbird.

Itscurious habit of laying the eggs in the nests of other birds, is so well-known that it is hardly worth while to reiterate it here.

It leaves this region about the middle of November, and the writer has never observed a single specimen at a later date. Its note is peculiar, forming a long-drawn whistle, rather high pitched.

Agelaius phoeniceus (Linn.). Red-winged Blackbird.

It would seem that there is hardly a bird better known by everybody, and particularly by our gunners, both young and old, than this "Blackbird," not even excepting the Robin and Bluebird; nevertheless, it is frequently confounded with the "Rusty-winged Blackbird," and even with the "Cowbird." Although the bird is seen throughout the whole year, yet a vast difference appears in their numbers according to the season. 
As early as February, flocks of those which had left in the preceding fall make their appearance, in numbers constantly - increasing as the season advances, especially during March and April ; but as May approaches, it ceases to gather in flocks, because the time for nesting has arrived. But it is not until the later part of August, when the "wild oats" Zizania aquatica begins to ripen, that its numbers are again seen to increase. By September and October its flocks, augmented by the young ones, become actually incalculable, as may be seen by anyone who will visit at that time the "Back river," or the "Patapsco." In November its numbers gradually decrease. But throughout the winter we may observe small flocks, or sometimes a solitary specimen, in secluded or sheltered places. Most of those that we have obtained and observed during winter were young birds, particularly those which were solitary.

Its usual note is a well-known cluck, delightful only to the gunner; but it has, besides, a few pleasant notes which, sound like "Cong-ter-ri," each syllable of which is uttered distinctly, but rapidly. In spring, particularly, these notes may be heard, but not only during that season, since in the cold weather of mid-winter we have occasionally recognized them.

\section{Sturnella magna (Linn.). Meadow Lark.}

This bird, which is usually called "Field Lark," stays in this region throughout the entire year. During summer it is evenly distributed all over the country, frequenting fields, meadows, pastures and similar places. In the fall, particularly in November, and even the greater part of winter, it collects in flocks of not very great number. Whether flying or on the ground, the individuals keep together, but not closely. When disturbed, the scattered flocks move off quite simultaneously. During the latter part of fall, and also during winter, it appears much more common in the immediate vicinity of the city than during the summer months.

It almost always keeps to the ground, where it runs about with great ease, while it is well protected by the color of its plumage, especially when the grass and weeds are bleached, so 
as to give the grayish and brownish tints, which well agree with the upper surface of the bird.

A nest now before me, obtained the latter part of June, is composed mainly of grasses, fine rootlets and feathers of the turkey. It was found, as is always the case, on the ground, and was partly arched over.

The eggs, three in number, are much smaller than the ordinary average size for such birds, and their color is whitish, speckled with purplish-brown, more thickly ne.ır the larger end, but sparsely near the middle and smaller end.

It gives forth a very pleasant song, but not strong when we consider the size of the bird.

During winter it is comparatively mute, and so continues until about April, when its well-known notes are again echoed through the air.

\section{Icterus spurius (Linn.). Orchard Oriole.}

The "Orchard Oriole" arrives here early in May, and stays all through the summer. In September it departs, rather early, long before the majority of our other songsters are ready to leave. During its stay, this bird is particularly fond of the orchards, whence its name, but it also frequents other cultivated places. The writer has also observed it along the roadside in bushes, shrubs and small trees.

It is not uncommon in various places, but is hardly entitled to be called abundant in the strict sense of the word.

It is difficult to give an adequate idea of its notes, by either words or syllables.

\section{Icterus galbula (Linn.). Baltimore Oriole.}

This beautiful bird, notwithstanding its name, is not a common summer visitor; at any rate, it is less common than the Orchard Oriole. It is evidently partial to eertain districts, while it shuns others, and therefore is not equally distributed over the country. We may remark incidentally that the original Latin name bestowed upon it by Linnæus did not refer to the city of Baltimore, but to the heraldric colors of Lord Baltimore. 
The Oriole arrives here carly in May, and is then for a few weeks rather common, much more so than during summer. It 'frequents shady trees, often near the farm house, showing a fondvess for the neighborhood of man, and during migration especially is not unfrequently seen even in the larger parks and cemeteries of the city. It leaves this neighborhood rather early in September.

The nest is pensile, more or less a pouch-like structure, composed of all possible kinds of soft material, almost artificially woven together. The eggs are of a whitish ground color, marked with dark so-called peu lines.

The song is a rather soft whistle, quite pleasant to hear; often uttered as the bird hops to and fro among the branches of the tree.

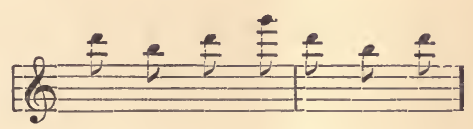

Quiscalus quiscula (Linn.). Purple Grackle.

The "Crow Blackbird," as it is commonly called, arrives here about the third week in March. It is a very common bird during summer, particularly in and near cultivated places, and frequenting parks and open places in the city. For several consecutive years we have observed this bird to be a regular visitor of the Greenmount Cemetery, from the latter part of March nearly through August, when it disappears. Early in April it is seen building rather bulky nests on the large trees which adorn that cemetery. From there it makes excursions into the surrounding fields, pastures and waste places, strutting about in a manner betraying its resemblance to the crow.

The usual call notes are almost the same as those of the common blackbird.

Towards the close of fall it departs for the south.

Corvus americanus (Aud.). American Crow.

Our "Crow" is such a common and well known bird that it is well nigh useless to offer any remarks concerning it. It is seen to be a resident, plentifil in summer as well as in winter, 
frequenting localities of all descriptions, now running over some cultivated field, then gathering upon some swampy, muddy shore, or along the road.

The crow builds rather early. The nest is a somewhat course and rough looking structure, situated usually at a considerable distance from the ground, on a tree, very often of the pine species. A nest with three nestlings almost ready to fly was obtained by the writer early in May.

A well known fact is their gathering in immense numbers at certain roosting places, in tracts of woods, from whence they start regularly in the morning, and return in the evening, always flying in a particular direction.

Cyanocitta cristata (Linn.). Blue Jay.

This fine and stately-looking bird is likewise a resident, but its numbers vary somewhat according to the season. Both in the spring and in the fall it is exceedingly common in the immediate vicinity of the city, particularly during October and the greater part of November, when it gathers in small flocks, flies from tree to tree, and is readily recognized by the screeching notes. But during summer, and still more during winter, it retires to the depths of the woods and to the interior of the country, so that hardly any are to be seen within a few miles of the city. In the month of July, while traversing the woods along the middle Patuxent river, the writer never before saw so many gathered together, hovering between the gigantic trees which border both sides of that river.

The usual notes of this bird are of a rather crying and screaming character, and far from pleasant.

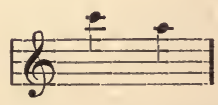

When assembled together their screaming sometimes becomes rather annoying. "' But besides this unpleasant screaming, the Jay possesses a few notes so plaintive, and so at variance with the vivacity and boldness of the bird, that we could hardly believe the 
fact when these notes were heard for the first time. The sounds consist mainly of two notes, a small third apart, uttered slowly.

- The Jay possesses, likewise, courage and boldness, in which qualities it is hardly exceeded by any of our other birds. The writer has observed on one occasion a Jay to attack a bird which appeared to be a Red-shouldered Hawk, and which it succeedcd, by persistent onsets, in driving away.

\section{Tyrannus tyrannus (Linn.). Kingbird.}

This bird makes its appearance about the twentieth of April. It is one of our most abundant birds during the whole summer, but leaves us again rather early in September. The bird may be found everywhere except in heavy woods; it particularly loves pastures and fields covered here and there with some tall weeds and plants, upon which to rest. It is also found near the farm house, along the roadside, often sitting on telegraph wires in company with others of its own kind. The bird is very bold and aggressive, attacking other birds much larger than itself, thus giving force to both its common and Latin names, as also to its former specific name, "intrepidus."

From its habit of catching bees, it is called "Bee Martin," which, in fact, is the only name given to it by our farmers. From this propensity to catch bees, this bird is very much disliked by country people.

The nest is rather bulky, not very neat, made of rootlets, as also of parts of grape vine bark, and it is lined with grass. The eggs are whitish, with spots of chestnut and lilac gray.

The bird has no particular utterance or notes, save a sort of twitter.

\section{Myiarchus crinitus (Linn.). Crested Flycatcher.}

I ate in April this bird, the largest of our flycatchers, makes its appearance, and it departs again about the 20th of September. It frequents mostly shady woods, and is hardly ever seen near houses and on the farms. Its note is nothing but a squeak, very different from the utterances of our other flycatchers, being low, and frequently heard when the bird is perched at the top of 
some tall tree. In September it apparently becomes mute. It is not uncommon, and it is generally distributed all over the country in suitable localities. Unlike the "Kingbird" and our two Pewees, it is hardly known to our farmers, notwithstanding its conspicuous size. It is always solitary, and does not appear to seek the company even of its own kind.

\section{Sayiornis phobbe (Lath.). Phœbe. \\ "Pewee."}

Setting aside the Bluebird and the Robin, both being seen occasionally, if not regularly during winter, the "Pewee" must be considered as the pioneer of all the birds in spring; it is truly a harbinger of spring. Early in March it arrives in this latitude, and is during that month and part of the following one very abundant, until the arrival of the "Wood Pewee," when it becomes outnumbered by that species. At this time also a large number evidently go farther north. All through the summer, even though common, it is not as abundant as the Wood Pewee. In the fall, particularly in October, it again becomes extremely abundant. It remains nearly through October, and we have observed it besides early in November. It is particularly fond of the neighborhood of water, and the writer has often observed it flying above the water, almost skimming it; somewhat after the manner of swallows, particularly in the spring.

Its notes are indicated by its vernacular name, and they are mostly heard in spring, uttered when sitting on some limb or branch of a tree, but sometimes while perched on a fence-rail. The notes sound like the syllables, "Pa-way."

\section{Contopus virens (Linn.). Wood Pewee.}

The Wood Pewee arrives in this neighborhood about the 25th of April, stays here through September, and leaves again in October. It is an exceedingly common bird all through the summer, much more so than the true Pewee. It frequents woodlands, also orchards and other similar localities, particularly during the breeding season, where it usually occupies the branches having none or hardly any foliage; seemingly as if 
the bird intended to have a full view of all that is going on. There we hear its plaintive notes, rather different from those of - the Pewee proper, throughout most of the summer, and occasionally even in September. The notes are "Pee-a-wee."

It breeds as well in the depths of the woods as in the orchards. The nest is an exceedingly beautiful structure, round, almost circular, made mostly of soft material of various kinds. The ontside, which indeed gives the nest its beautiful appearance, is covered with bluish-gray lichens. The nest is always, as far as we have had occasion to observe, saddled on the branch of the tree, which consequently gives its lower part a very decided indent. It is sometimes attached in the orchard to an apple tree, probably eight or ten feet from the ground. One was obtained by the writer from a tree where it was situated at a height of at least twenty-five feet from the ground. The eggs are four or five in number, with dark brownish spots, some of which are placed like a ring around the larger end. We have found a nest late in July with eggs upon which the birds had not yet begun to incubate.

\section{Empidonax acadicus (Gmel.). Acadian Flycatcher.}

\section{Small Green-crested Flycatcher.}

This flycatcher, by its greenish color, is easily distinguished from the rest of the "Tyrannidae" inhabiting our woods during summer. It arrives from the South about the first week in May. It is moderately common all through the summer, frequenting only" shady woods, and preferring usually the lower parts of the trees, and not seeking disguise in the foliage, as if conscious of the protection afforded by its color. It seems to be of a rather solitary nature. Toward the close of September it departs to seek a more congenial climate for its winter home.

This bird is entirely destitute of song or anything which might be so designated. Only a squeaky note, rather loud for the size of the bird, is heard occasionally, which betrays the bird, as we pass through the woods. When driven away by a stranger it does not fly very far, but soon alights on some bough of a tree near at hand. 


\section{LIST OF GENERA AND SPECIES.}

1. Turdas mustelinus.

2. Turdus unalascae Palasii.

3. Merula migratoria.

4. Galeoscoptes carolinensis.

5. Harporhynchus rufus.

6. 'Sialia sialis.

7. Parus bicolor.

8. Parus carolinensis.

9. Sitta carolinensis.

10. Thryothorus ludovicianus.

11. Troglodytes aëdon.

12. Cistothorus palustris.

13. Mniotilta varia.

14. Helmintherus vermivorus.

15. Dendroica æstiva.

16. Dendroica discolor.

17. Dendroica vigorsii.

18. Seiurus aurocapillus.

19. Seiurus motacilla.

20. Geothly pis trichas.

21. Icteria viridis.

22. Sylvania canadensis.

23. Setophaga ruticilla.

24. Vireo olivaceus.

25. Vireo noveboracensis.

26. Vireo flavifrons.

27. Ampelis cedrorum.

28. Chelidon erythrogaster.

29. Tachycinetta bicolor.

30. Progne subis.
31. Petrochelidon lunifrons.

32. Clivicola riparia.

33. Stelgidopteryx serripennis.

34. Piranga erythromelas.

35. Piranga rubra.

36. Spinus tristis.

37. Poocetes gramineus.

38. Amodromus savannarum passerinus.

39. Amodromus maritimus.

40. Melospiza fasciata.

41. Spizella pusilla.

42. Spizella socialis.

43. Pipilo erythrophthalmus.

44. Cardinalis cardinalis.

45. Passerina cyanea.

46. Spiza americana.

47. Molothrus ater.

48. Agelaius phoeniceus.

49. Sturnella magna.

50. Icterus spurius.

51. Icterus galbula.

52 Quiscalus quiscula.

53. Corvus americanus.

54. Cyanocitta cristata.

55. Tyrannus tyrannus.

56. Myiarchus crinetus.

57. Sayiornis phoebe.

58. Contopus vivers.

59. Empidonax acadicus. 
QI Resler -

684 $125 R 3$ resident in summer near the city of Ealtimore

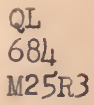


This book is DUE on the last date stamped below.

20. Geothlypis trichas.

21. Icteria viridis:

22. Sylvania canadensis.

23. Setophaga ruticilla.

24. Vireo olivaceus.

25. Vireo noveboracensis.

26. Vireo flavifrons.

27. Ampelis cedrorum.

28. Chelidon erythrogaster.

29. Tachycinetta bicolor.

30. Progne subis.

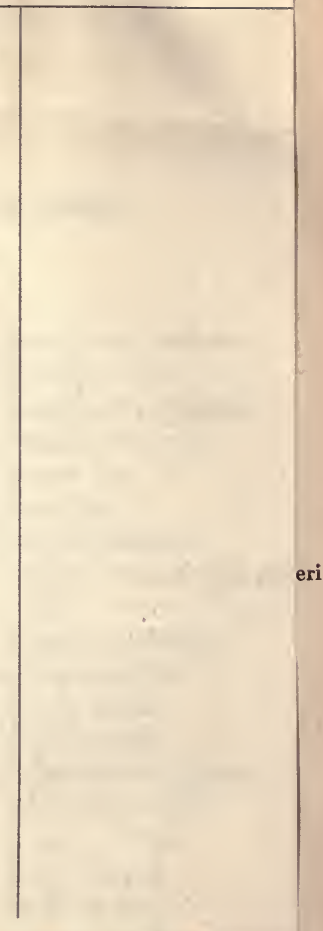

20. Ageraruo procriceus.

49. Sturnella magna.

50. Icterus spurius.

51. Icterus galbula.

52 Quiscalus quiscula.

53. Corvus americanus.

54. Cyanocitta cristata.

55. Tyrannus tyrannus.

56. Myiarchus crinetus.

57. Sayiornis phoebe.

58. Contopus vivers.

59. Empidonax acadicus. 


$$
\begin{aligned}
& \text { QI Resler - } \\
& 684 \text { Iist of birds } \\
& \text { r.25R3 resident in } \\
& \text { summer near } \\
& \text { the city of Daltimore }
\end{aligned}
$$

QL

684

M25R3 
